\title{
A COVID-19-Related Kawasaki Disease: Our First Multi-system Inflammatory Syndrome in Children Case
}

\section{COVID-19 İlişkili Kawasaki Hastalığı: İlk Çocukluk Çağı Multisistem Enflamatuvar Sendrom Tanılı Olgumuz}

\author{
(D) Ülkem Koçoğlu Barlas1, (D Sertaç Hanedan Onan2, (D) Meltem Erol3 \\ ${ }^{1}$ University of Health Sciences Turkey, İstanbul Bağcılar Training and Research Hospital, Clinic of Pediatrics, Pediatric Intensive Care Unit, \\ İstanbul, Turkey \\ 2University of Health Sciences Turkey, İstanbul Bağcllar Training and Research Hospital, Clinic of Pediatrics, Division of Pediatric Cardiology, \\ İstanbul, Turkey \\ ${ }^{3}$ University of Health Sciences Turkey, İstanbul Bağcılar Training and Research Hospital, Clinic of Pediatrics, İstanbul, Turkey
}

\section{Abstract}

A new type of coronavirus disease-2019 (COVID-19) epidemic, which started in the last months of 2019, has spread rapidly all over the world and caused many deaths, especially in adults. Recently, a syndromic condition caused by the hyperinflammatory response that is thought to be due to this new pandemic coronavirus factor has been identified, especially in the childhood age group. It has been stated that this response is particularly similar to Kawasaki disease and can manifest itself with multiorgan involvement. This new clinical condition was defined as pediatric inflammatory multi-system syndrome temporally associated with severe acute respiratory syndrome-coronavirus 2 or multi-system inflammatory syndrome in children associated with COVID-19.

In this case presentation, a nine-year-old male patient was admitted to our emergency department with complaints similar to ones in Kawasaki disease. The patient was followed up in our pediatric intensive care unit due to hypotension and myocarditis, as well as likely macrophage activation syndrome and simultaneous COVID-19 positivity. For Kawasaki disease, intravenous immunoglobulin, acetylsalicylic acid, low molecular weight heparin and methylprednisolone; for myocarditis, enalapril and furosemide; and for COVID-19, favipiravir was administered to the patient. We would like to present our case to exemplify clinicians dealing with pediatric patients and to assist in easier recognition, prevention, diagnosis and treatment of COVID-19 in all children worldwide.

Keywords: Children, COVID-19, multi-system inflammatory syndrome

\section{Öz}

2019 yılının son aylarında başlayan yeni tip koronavirüs hastalığı-2019 (COVID-19) salgını tüm dünyada hızla yayıldı ve erişkinler başta olmak üzere çok sayıda ölüme yol açtı. Son zamanlarda ise özellikle çocuk yaş grubunda bu yeni pandemik koronavirüs etkenine bağlı olduğu düşünülen hiperenflamatuvar yanıtın neden olduğu sendromik bir durum tanımlandı. $\mathrm{Bu}$ yanıtın özellikle Kawasaki hastalığına benzediği ve multiorgan tutulumuyla kendini gösterebileceği belirtildi. Bu yeni klinik durum, geçici olarak ağır akut solunum sıkıntısı sendromu-koronavirüs 2 ile ilişkili pediyatrik enflamatuvar multi-sistem sendrom veya COVID-19 ile ilişkili çocukluk çağı multi-sistem enflamatuvar sendrom olarak tanımlandı. Bu sunumda acil servisimize Kawasaki hastalığına benzer şikayetlerle başvuran dokuz yaşında erkek bir hasta anlatıldı. Hasta hipotansiyon, myokardit, olası makrofaj aktivasyon sendromu ve eş zamanlı COVID-19 pozitifliği nedeniyle çocuk yoğun bakım ünitemizde takip edildi. Kawasaki hastalığı için intravenöz immünoglobülin, asetilsalisilik asit, düşük molekül ağırlıkı heparin ve metilprednisolon, myokardit için enalapril ve furosemid, COVID-19 için favipiravir kullanıldı. Olgumuzu çocuk hastalarla uğraşan klinisyenlere örnek teşkil edebilmek ve dünya çapındaki tüm çocuklarda COVID-19'un daha kolay tanınması, önlenmesi, teşhisi ve tedavisi için yardımcı olabilmek adına sunmak istedik.

Anahtar kelimeler: Çocuk, COVID-19, multi-sistem enflamatuvar sendrom

Address for Correspondence: Ülkem Koçoğlu Barlas, University of Health Sciences Turkey, İstanbul Bağcılar Training and Research Hospital, Clinic of Pediatrics, Pediatric Intensive Care Unit, İstanbul, Turkey

E-mail: ulkemkocoglu@yahoo.com ORCID ID: orcid.org/0000-0001-7445-5858 Received: 24.05.2021 Accepted: 28.06.2021

Cite this article as: Koçoğlu Barlas Ü, Onan SH, Erol M. A COVID-19-Related Kawasaki Disease: Our First Multi-system Inflammatory Syndrome in Children Case. Bagcilar Med Bull 2021;6(3):350-354

${ }^{\odot}$ Copyright 2021 by the Health Sciences University Turkey, Bagcilar Training and Research Hospital Bagcilar Medical Bulletin published by Galenos Publishing House. 


\section{Introduction}

Cases of Kawasaki disease (KD) or cases with Kawasakilike clinical manifestations, which have recently been accompanied by the new type of coronavirus [severe acute respiratory syndrome-coronavirus-2 (SARS-CoV-2), coronavirus disease-2019 (COVID-19)], are gradually emerging (1). In this case presentation, we wanted to present incomplete KD (IKD) due to the progression of hypotension, myocarditis and macrophage activation syndrome (MAS), and simultaneous COVID-19 positivity was detected, which was treated successfully.

\section{Case Report}

A nine-year-old male patient was admitted to the pediatric emergency department with a five-day history of fever, vomiting, diarrhea, headache and abdominal pain. In his first examination, he was conscious and orientated and he had bilateral conjunctival injection, changes in lips and oral mucosa, and strawberry tongue. Scrotal edema was detected in the urogenital system examination. The first examinations of the patient conducted in the emergency room are shown in Table 1 , in the second column ( $1^{\text {st }}$ day). Echocardiography performed on the admission was normal. The examinations of the patient, who was hospitalized and followed up in our service, are shown in Table 1 , in the third column ( $2^{\text {nd }}$ day). Ceftriaxone was started due to the possibility of urinary tract infection and a pediatric surgery opinion was requested for acute appendicitis. On the second day of hospitalization, fever and diarrhea complaints continued at the same intensity and COVID-19 reverse transcription polymerase chain reaction (RT-PCR) was negative. Antibiotic therapy was replaced by vancomycin and meropenem due to no improvement in the clinical findings of the patient. Moreover, physical examination, as well as accompanying laboratory findings including elevated erythrocyte sedimentation rate (ESR), C-reactive protein (CRP) and procalcitonin levels, neutrophil predominance in blood tests, IKD, was considered, and acetylsalicylic acid (ASA) treatment at a dose of $80 \mathrm{mg} / \mathrm{kg} /$ day with intravenous immunoglobulin (IVIG) at a dose of $2 \mathrm{~g} / \mathrm{kg}$ was started. On the third day of his hospitalization, fever and diarrhea complaints continued, and were accompanied by hypotension (81/33 $\mathrm{mmHg}$ ), hyperferritinemia, hypertriglyceridemia and thrombocytopenia (Table 1, fourth column, $3^{\text {rd }}$ day), and the patient was hospitalized in pediatric intensive care unit (PICU) with the consideration of possibility of MAS.
The examinations performed on the first day of PICU monitoring are shown in Table 1 , in the fifth column $\left(4^{\text {th }}\right.$ day). Noradrenaline infusion was started at a dose of $0.05 \mu \mathrm{g} / \mathrm{kg} / \mathrm{min}$ with human albumin at a dose of $1 \mathrm{~g} / \mathrm{kg}$. The second IVIG treatment was given 36 hours after the first IVIG treatment as the fever continued. The second echocardiography performed on the eighth day of the onset of complaints revealed mild dilatation in the left ventricle and decreased systolic functions, mitral valve insufficiency, hyperechogenicity and dilatation in the left coronary artery wall, and minimal pericardial effusion (Image 1,2). Due to the current physical examination findings, echocardiographic findings, laboratory findings [(N-terminal pro-B-type natriuretic peptide (NT-proBNP) $6.950 \mathrm{ng} / \mathrm{L}$ (normal: 0-133 ng/L), troponin I $24.5 \mathrm{pg} / \mathrm{mL}$ (normal: 0-19.8 pg/mL)] and hypotension of the patient, evaluated as KD shock syndrome (KDSS) and myocarditis, ASA treatment was continued and furosemide, enalapril and low-molecular weight heparin were added to the treatment. The patient was positive for COVID-19 IgM and IgG, for

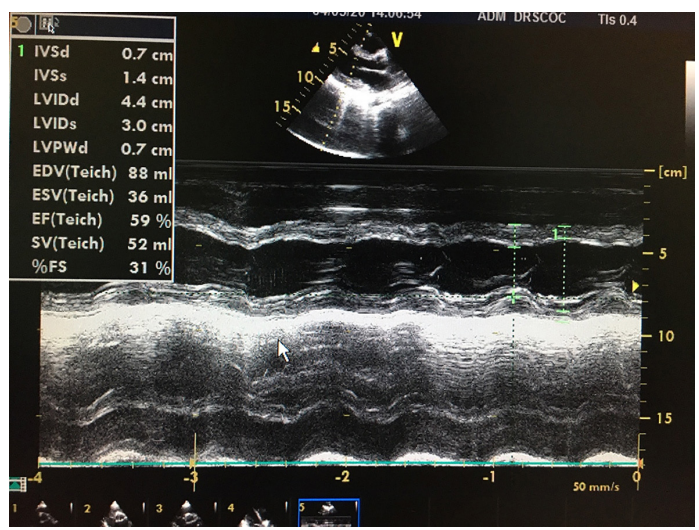

Image 1. Decreased systolic functions in echocardiography of the patient

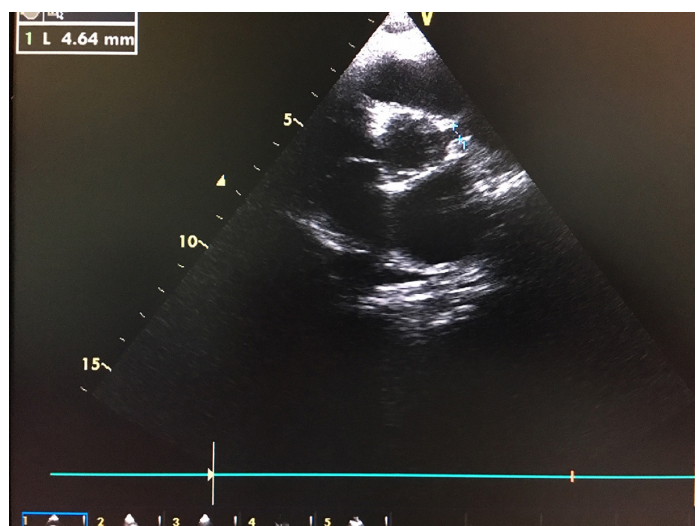

Image 2. Minimal pericardial effusion in echocardiography of the patient 
which the test kit used in our hospital is based on the lateral flow immunochromatographic test for COVID-19 IgM and IgG antibodies. On the fourth day of intensive care followup [laboratory values are shown in Table 1, in the sixth column ( $7^{\text {th }}$ day)], methylprednisolone at a dose of $2 \mathrm{mg} /$ $\mathrm{kg} /$ day and favipiravir (FPV) were added to the treatment schedule because, 36 hours after the second IVIG treatment, there was no reduction in fever and there was an active left ventricular dysfunction. The patient did not need inotropes three days after hospitalization in PICU, there was no fever after the second IVIG treatment, the complaint of diarrhea was reduced and ceased. In the third echocardiography, regression in left ventricular dilation with cardiac functions within normal limits, and minimal mitral valve failure were observed as well as regression in the previous dilation of left coronary artery wall. He was discharged on the $13^{\text {th }}$ day of hospitalization. Laboratory parameters examined before discharge are shown in Table 1 , in the last column (13 ${ }^{\text {rd }}$ day).

Table 1. The patient's laboratory findings

$1^{\text {st }} \quad 2^{\text {nd }} \quad 3^{\text {rd }} \quad 4^{\text {th }} \quad 7^{\text {th }} \quad 13^{\text {th }}$

day day day day day day

\begin{tabular}{lllllll} 
WBC & 13.25 & 8.45 & 7.91 & 9.28 & 9.38 & 8.30 \\
Neu & 12.05 & 7.20 & 5.88 & 6.72 & 4.45 & 3.70 \\
Lym & 0.60 & 0.50 & 1.03 & 1.04 & 2.27 & 3.57 \\
Hgb & 12.60 & 11.30 & 9.80 & 9.40 & 9.00 & 9.70 \\
Htc & 36.10 & 33.50 & 28.00 & 27.30 & 26.60 & 30.60 \\
PIt & 180 & 161 & 146 & 172 & 275 & 475 \\
ESR & - & 33 & - & 52 & 49 & - \\
CRP & 154.79 & 114.61 & - & 91.9 & 20.87 & 3.18 \\
PCT & - & 31.53 & 29.80 & 20.90 & 1.49 & 0.09 \\
Ferritin & - & - & 1500 & 1396.9 & 397.7 & 380.8 \\
Triglyceride & - & - & 300 & - & 286 & - \\
Fibrinogen & - & - & 624 & 398 & 335 & - \\
Na & 123 & 125 & 127 & 131 & 134 & 134 \\
Albumin & 3.21 & 2.96 & 2 & 2.36 & - & 2.72 \\
IL-6 & - & - & - & - & 24 & 2 \\
D-dimer & - & 0.11 & - & 3.37 & - & 2.28 \\
NT-proBNP & - & 6.410 & - & - & 6.950 & 60 \\
\hline
\end{tabular}

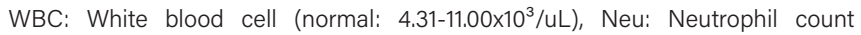

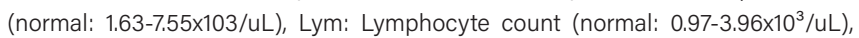
Hgb: Hemoglobin (normal: 10.7-13.4 g/dL), Htc: Hematocrit (normal: 32.2\%-39.8), Plt: Platelet count (normal: $206-369 \times 10^{3} / \mathrm{uL}$ ), ESR: Erythrocyte sedimentation rate (normal: $0.00-15.00 \mathrm{~mm}$ ), CRP: C-reactive protein (normal: $0-5 \mathrm{mg} / \mathrm{L}$ ), PCT: Procalcitonin (normal: 0.02-0.5 ng/mL), Ferritin (normal: $23.9-336.2 \mathrm{ng} /$ $\mathrm{mL}$ ), Triglyceride (normal: 0-150 mg/dL), Fibrinogen (normal: $200-400 \mathrm{mg} / \mathrm{dL}$ ), Na: Sodium (normal: 136-146 mmol/L), Albumin (normal: 3.5-5.2 g/dL), IL-6: Interleukin 6 (normal: $<7 \mathrm{pg} / \mathrm{mL}$ ), D-dimer (normal: 0.00-0.50 ug FEU/mL), NTproBNP: N-terminal pro-B-type natriuretic peptide (normal: 0-133 ng/L)

\section{Discussion}

While prolonged fever accompanying four of the five classical findings makes the diagnosis of typical $\mathrm{KD}$, the American Heart Association guidelines published in 2017 defined the patients having less than four findings with the laboratory findings such as ESR, CRP elevation, hypoalbuminemia, leukocytosis, and echocardiography findings such as left ventricular dysfunction as having IKD (2). In the acute phase, which is the first of the three phases of the disease, patients may present the clinical manifestation with valvulitis, myocarditis, pericarditis and KDSS (3). KDSS is characterized by hypotension, a decrease in basal systolic blood pressure by at least $20 \%$, or signs of peripheral hypoperfusion (4). While the hypotension of patient was suggesting KDSS, it was thought that it did not fully meet MAS criteria due to the absence of organomegaly and the absence of hypofibrinogenemia (5), and the gradual decrease of ferritin in clinical follow-up led to avoiding this diagnosis.

Verdoni et al. (6) identified a new clinical type, which they called Kawasaki-like disease while comparing KD cases seen before and after a pandemic in their study. This type is characterized by prominent lymphopenia, thrombocytopenia and increased ferritin level, clinically leading to myocarditis, and a more severe disease progression with IVIG resistance, requirement of steroid use, biochemical markers of MAS and clinical characteristics similar to KDSS. Since the same condition is also observed in COVID-19 patients, especially due to the fact that our patient had long-term and severe complaints of diarrhea and fever, as well as lymphopenia, thrombocytopenia, D-dimer, ferritin and IL-6 elevation in the laboratory tests, a fever that was resistant to IVIG treatment and requirement for starting steroid treatment, and clinical manifestations of MAS and KDSS and the presence of myocarditis, we also considered diagnosis of COVID-19. The negative results of two RT-PCR tests for COVID-19 did not lead us to avoid the diagnosis because Riphagen et al. (7) mentioned the presence of a hyperinflammatory associated with COVID-19 condition in the patients that had been undergoing intensive care with similar complaints, the respiratory system findings were not at the forefront, and RT-PCR tests were negative. This condition has been associated with severe cytokine storm syndrome and even ventricular dysfunction caused by it in adult COVID-19 patients (8). Such cardiac findings may also result in myocarditis as a result of viremia in some viral diseases (9). We also considered a hyperinflammatory process that was 
associated with COVID-19 in our patient and included FPV in his treatment due to existing myocarditis. In the study performed by Cai et al. (10), comparing FPV with lopinavir/ ritonavir combination, the median time of viral clearance was significantly lower, the improvement rate in computed tomography scans was higher and the side effect rate was lower in the FPV group. No side effects were observed in our patient during short-term use.

In recent months, there has been an increase in admissions of children with clinical findings similar to KD, KDSS and toxic shock syndrome. This new clinical condition was defined as pediatric inflammatory multisystem syndrome temporally associated with SARS-CoV-2 (PIM-TS) or multi-system inflammatory syndrome in children (MIS-C) associated with COVID-19 (11). The diagnostic criteria of disease were determined by the World Health Organization (WHO) (12), the Royal College of Pediatrics and Child Health (13), and the centers for disease control and prevention (14). According to the definition of the WHO, fever of three days or more and elevated inflammatory markers between 0 and 19 years of age were accompanied by two of the following criteria: rash or bilateral non-purulent conjunctivitis or oral, hands, or feet mucocutaneous inflammation signs; hypotension or shock; features of myocardial dysfunction, pericarditis, valvulitis, or coronary abnormalities (echocardiogram findings or elevated troponin or NT-proBNP); evidence of coagulopathy (elevated prothrombin time, partial thromboplastin time, D-dimers) and acute gastrointestinal problems (diarrhoea, vomiting, or abdominal pain). The Royal College of Pediatrics and Child Health defined fever and elevated inflammatory markers as single or multiple organ dysfunction in children without specifying any age range. Centers for disease control and prevention included patients under 21 years of age with severe disease requiring hospitalization and multi-organ involvement for fever and elevated inflammatory markers. The common feature in all three definitions was that this condition could not be explained by another clinical condition nd positive PCR or antigen tests or contact with a COVID-19 positive person. We accepted our patient as MIS-C because he complied with the criteria listed.

\section{Conclusion}

In this case report, we wanted to present one of these different clinical manifestations caused by the new type of coronavirus and to share this relationship with the clinicians dealing with the same age group of children. In the future, multicenter research on the relationship between the new type of coronavirus and $\mathrm{KD}$ will enable us to better understand the relationship of this virus with KD, and perhaps to control the KD that increases periodically and sometimes be fatal. We think that MIS-C, which develops after COVID-19 infection, will be more easily recognized with the understanding of its pathophysiological mechanisms. With easier recognition of the disease, it will be easier to initiate proven treatment mechanisms.

\section{Ethic}

Informed Consent: Consent was obtained from the family to use information about the patient.

Peer-review: Externally peer-reviewed.

\section{Authorship Contributions}

Follow-up of the Case: Ü.K.B., M.E., S.H.O., Literature Search: S.H.O., M.E., Writing: Ü.K.B., M.E., S.H.O., Manuscript Review and Revisation: Ü.K.B., M.E.

Conflict of Interest: No conflict of interest was declared by the authors.

Financial Disclosure: The authors declared that this study received no financial support.

\section{References}

1. Jones VG, Mills M, Suarez D, Hogan CA, Yeh D, Segal JB, et al. COVID-19 and Kawasaki Disease: Novel Virus and Novel Case. Hosp Pediatr 2020;10(6):537-540.

2. McCrindle BW, Rowley AH, Newburger JW, Burns JC, Bolger AF, Gewitz M, et al. Diagnosis, treatment, and long-term management of Kawasaki disease: a scientific statement for health professionals from the American Heart Association. Circulation 2017;135(17):927-999.

3. Weiss PF. Pediatric vasculitis. Pediatr Clin North Am 2012;59(2):407423.

4. Kanegaye JT, Wilder MS, Molkara D, Frazer JR, Pancheri J, Tremoulet AH, et al. Recognition of a Kawasaki disease shock syndrome. Pediatrics 2009;123(5):783-789.

5. Ravelli A, Minoia F, Davi S, Horne A, Bovis F, Pistorio A, et al. 2016 Classification criteria for macrophage activation syndrome complicating systemic juvenile idiopathic arthritis: a european league against rheumatism/american college of rheumatology/ paediatric rheumatology international trials organisation collaborative initiative. Ann Rheum Dis 2016;68(3):566-576.

6. Verdoni L, Mazza A, Gervasoni A, Martelli L, Ruggeri M, Ciuffreda $\mathrm{M}$, et al. An outbreak of severe Kawasaki-like disease at the Italian epicentre of the SARS-CoV-2 epidemic: an observational cohort study. Lancet 2020; 395(10239):1771-1778.

7. Riphagen S, Gomez X, Gonzalez-Martinez C, Wilkinson N, Theocharis P. Hyperinflammatory shock in children during covid-19 pandemic. Lancet 2020;395(10237):1607-1608.

8. Jacobs JP, Stammers AH, St Louis J, Hayanga JWA, Firstenberg MS, Mongero LB, et al. Extracorporeal membrane oxygenation in 
the treatment of severe pulmonary and cardiac compromise in COVID-19: Experience with 32 patients. ASAIO J 2020;66(7):722730 .

9. Loomba RS, Villarreal E, Flores S. Covid-19 and Kawasaki syndrome: should we really be surprised? Cardiol Young 2020;30(7):10591060 .

10. Cai Q, Yang M, Liu D, Chen J, Shu D, Xia J, et al. Experimental treatment with Favipiravir for COVID-19: An Open-Label Control Study. Engineering (Beijing) 2020;6(10):11921198.

11. Jiang L, Tang K, Levin M, Irfan O, Morris SK, Wilson K, et al. COVID-19 and multisystem inflammatory syndrome in children and adolescents. Lancet Infect Dis 2020;20(11):e276-e288.
12. WHO. Multisystem inflammatory syndrome in children and adolescents with COVID-19. Last Accessed Date: 16.07.2020. Available from: https://www.int/publications/i/item/multisysteminflammatory-syndrome-in children-and-adolescents-with-covid-19.

13. The Royal Collage of Paediatrics and Child Health. Guidancepaediatric multisystem inflammatory syndrome temporally associated with COVID-19 (PIMS). 2020. Last Accessed Date: 16.07.2020. Available from: https://www.rcpch.ac.uk/resources/ guidance-paediatric-multisystem-inflammatory-sydrometemporally-associated-covid-19-pims.

14. Centers for Disease Control and Prevention. Multisystem inflammatory syndrome. 2020. Last Accessed Date: 16.07.2020. Available from: https://www.cdc.gov/mis-c/hcp/. 